\title{
Fish consumption behavior and rates in native and non-native people in Saudi Arabia
}

\author{
Joanna Burger ${ }^{1,2}$, Michael Gochfeld ${ }^{2,3}$, Zenon Batang ${ }^{4}$, Nabeel Alikunhi ${ }^{4}$, Ramzi Al- \\ Jahdali $^{4}$, Dalal Al-Jebreen ${ }^{5}$, Mohammed A. M. Aziz ${ }^{6}$, and Abdulaziz Al-Suwailem ${ }^{4}$ \\ ${ }^{1}$ Division of Life Sciences, Rutgers University, Piscataway, NJ, USA \\ ${ }^{2}$ Environmental and Occupational Health Sciences Institute, Rutgers University, Piscataway, NJ, \\ USA \\ ${ }^{3}$ Environmental and Occupational Medicine, Rutgers-Robert Wood Johnson Medical School, \\ Piscataway, NJ, USA \\ ${ }^{4}$ Coastal and Marine Resources Core Laboratory, King Abdullah University of Science and \\ Technology, Thuwal, Saudi Arabia \\ ${ }^{5}$ Department of Nutrition and Food Science, Princess Nora bint Abdul Rahman University, \\ Riyadh, Saudi Arabia \\ ${ }^{6}$ Directorate of Aquatic Environment, Ministry of Agriculture, Riyadh, Saudi Arabia
}

\begin{abstract}
Fish are a healthy source of protein and nutrients, but contaminants in fish may provide health risks. Determining the risk from contaminants in fish requires site-specific information on consumption patterns. We examine consumption rates for resident and expatriates in the Jeddah region of Saudi Arabia, by species of fish and fishing location. For Saudis, $3.7 \%$ of males and 4.3 $\%$ of females do not eat fish; for expatriates, the percent not eating fish is $6.6 \%$ and $6.1 \%$ respectively. Most people eat fish at home (over $90 \%$ ), and many eat fish at restaurants (65\% and $48 \%$, respectively for Saudis and expatriates). Fish eaten at home comes from local fish markets, followed by supermarkets. Saudis included fish in their diets at an average of 1.4 \pm 1.2 meals/week at home and $0.8 \pm 0.7$ meals/week at restaurants, while expats ate $2.0 \pm 1.7$ meals/week at home and $1.1 \pm 1.1 \mathrm{meals} /$ week in restaurants. Overall, Saudis ate $2.2 \mathrm{fish}$ meals/week, while expats ate 3.1 meals/week. Grouper (Epinephelus and Cephalopholis) were eaten by $72 \%$ and $60 \%$ respectively. Plectropomus pessuliferus was the second favorite for both groups and Hipposcarus harid and Lethrinus lentjan were in $3^{\text {rd }}$ and $4^{\text {th }}$ place in terms of consumption. Average meal size was $68 \mathrm{~g}$ for Saudis and $128 \mathrm{~g}$ for expatriates. These data can be used by health professionals, risk assessors, and environmental regulators to examine potential risk from contaminants in fish, and to compare consumption rates with other sites.
\end{abstract}

\section{Keywords}

Fishing; Fish consumption; Saudi Arabia; Meal/week; Meal size 


\section{Introduction}

Fishing, and fish/shellfish consumption are important aspects of culture in many places in the world, particularly for coastal communities, as well as being a method of obtaining protein (Toth and Brown, 1997; IOM, 2006; Burger and Gochfeld, 2011). High fishing rates occur in many different cultures, including both rural and urban areas (Burger et al., 2001a,b; Bienenfeld et al., 2003), and in other regions of the world, particularly in Asia (Burger et al., 2003; Lu et al., 2008; Hsiao et al., 2011). Well over half of the world's population resides within $100 \mathrm{~km}$ of oceans, making it important to understand the factors that affect the health and safety of marine fish as a food source. Seafood consumption is generally increasing in many parts of the World, particularly for coastal communities (NOAA, 2004). In many places, fish and shellfish are the only readily available sources of protein that people can self-harvest, often throughout the year.

Fish provide high-quality protein, vitamins, and other nutrients that are essential to human health; regular fish consumption is widely promoted as part of a healthy diet (Sidhu, 2003; Verbeke and Vackier, 2005; Sioen et al., 2008, Sun, 2008). There is growing evidence that fish consumption reduces the risk of cardiovascular disease and has beneficial effects on fetal development during pregnancy (Olsen and Secher, 2002; Patterson, 2002; Olsen et al., 2006). Fish consumption is associated with low blood cholesterol (Anderson and Wiener, 1995), positive pregnancy outcomes, and better child cognitive test performances (Oken et al., 2008). Fish (and fish oil) contain omega-3 (n-3) fatty acids that reduce cholesterol levels and the incidence of heart disease, blood pressure, stroke, and pre-term delivery (KrisEtherton et al., 2002; Daviglus et al., 2002; Patterson, 2002; Mozaffarian and Rimm, 2006; Virtanen et al., 2008; Mozaffarian, 2009; Ramel et al., 2010).

Yet people are faced with deciding whether the benefits of eating fish outweigh the risks from contaminants. Consumption of fish, shellfish and other seafood is the primary source of exposure to contaminants (IOM, 2006), especially methylmercury and PCBs (NRC, 2000, Rice et al., 2000; Stern et al., 2004). Determining the effect of contaminants on humans and eco-receptors requires site-specific information on contaminant levels and consumption patterns (Burger et al., 1992; 1999, 2001a,b; NRC, 2000; IOM, 2006). Risk is a function of exposure and toxicity, and thus information must be available on both (Burger and Gochfeld, 2006).

Persistent contaminants, such as mercury, polychlorinated biphenyls (PCBs), organochlorine pesticides (OCPs), and other halogenated aromatic compounds, are among the environmental contaminants that remain from mining, manufacturing, military, transportation and agricultural activities. Some of the compounds are produced deliberately for commerce; others are unwanted byproducts or breakdown products. Although many of these compounds (PCBs, OCPs) have restricted use, or are banned in many countries, they remain as legacy waste that can accumulate in soils, sediment, water, and biota, including seafood. Many contaminants (e.g. metals, chlorinated hydrocarbons) can remain unchanged in the environment for decades, or longer, and others can be modified to daughter products that are also toxic and persistent (e.g. PCBs or other organics). Many of these chemicals 
bioaccumulate in organisms and can bioamplify as they move up the food chain, reaching concentrations that have deleterious effects on organisms and the predators that eat them (Downs et al., 1998).

The objective of this paper is to examine the consumption rates of native and non-native (expatriate) residents in the Jeddah coastal region of Saudi Arabia. Because of oil development in the region, there is a massive influx of expatriates (Feidi, 1998). Hence, it was important to understand whether consumption patterns differ for native versus nonnative residents. While our overall goal was to determine whether people are at risk from consuming fish from markets or from fish collected from the coastal waters surrounding Jeddah, the first step was to examine consumption rates, and we do so in this paper.

York and Gossard (2004) reported that after controlling for other factors, fish consumption rates in the Middle East and Africa were not significantly different from those in the West (defined to include the Americas, Europe, Australia, and New Zealand), and the effect of economic development on fish consumption tends to be the same for all non-Asian nations. In the Arab region, Feidi (1998) noted that fish consumption rates were highest in coastal states where fish is relatively abundant and human population is low; fish formed a major part of the national diet. However, the consumption rates were lower in inland Arab states as a result of low production levels, high human populations, and limited fish importation capability due to hard currency shortages. However, such studies are not available for Saudi Arabia at the regional level. The present study provides information on consumption for Saudi Arabians and expatriates living in the Jeddah region. Overall, the present study was part of study consisting of four parts: 1) fish consumption survey, 2) collection and contaminant analysis of popularly eaten fish, 3) risk evaluations and risk assessments, and 4) recommendations for fish consumption advisories and management of any potential risk to people from seafood in the coastal Jeddah area. Only fish consumption pattern will be examined in this paper.

\section{Methods}

Fish consumption was determined by interviewing people in a variety of locations about fishing, fish consumption, and attitudes about fishing. After developing a consumption questionnaire, we conducted a pilot study by interviewing 50 people, and modifying the questionnaire accordingly. Some questions pertaining to weight, income were subsequently dropped because of cultural sensitivity.

\subsection{Study area and population}

The present study was conducted in coastal city of Jeddah (Fig. 1), which is the largest urban center on the western seaboard of the Kingdom of Saudi Arabia. It is the second largest city in the Kingdom, after the capital Riyadh in the central mainland. The main urban area of Jeddah sprawls over a low-lying coastal plain that is bounded by the central Red Sea to the west and a chain of hills to the east (El-Shafie, 2009). The urban space has physically expanded 1000-fold to 176,500 ha from six decades ago (Abdulaal, 2012). From a small seaport and fishing settlement of about 30,000 people in the late 1940s, the Jeddah population has grown 10-fold at the start of 1970s, 100-fold by late 2000s, and may reach 
5.6 million by 2029 (Basaham et al., 2009; Abdulaal, 2012). This rapid population growth has been attributed to increased local migrations, higher influx of migrant workers and pilgrims, increased birth rate, and decreased mortality rate, all coinciding with the recent boom in the oil-based national economy (Aljoufie et al., 2012).

\subsection{Protocol for interviews}

Data were taken opportunistically by intercepting people to interview at fishing sites, markets, restaurants, malls, and schools $(\mathrm{N}=1000)$. Interviews were conducted in both English and Arabic, by experienced interviewers (both male and female) who were bilingual. The questionnaire solicited responses on individual and household fish consumption rates, fish choices and preferences, purchasing behavior, methods of fish preparation, and other attitudes toward fishing and fish consumption. Table 1 lists the names of the fish commonly reported eaten by the study population, along with their English and Saudi names.

\subsection{Protocol for determining consumption rates and significant differences}

The average fish consumption rate per household was estimated as follows:

$$
W_{i j}=c_{i} w_{i j} f_{i j}
$$

where $W_{i j}$ is the annual consumption of species $i$ by household $j$ (kg/day), $c_{i}$ is a factor indicating the portion of weight actually eaten for species $i, w_{i j}$ is the mean wet weight of species $i$ consumed by household $j$ per meal ( $\mathrm{kg} / \mathrm{meal})$, and $f_{i j}$ is the frequency of consumption of species $i$ by household $j$ (in meals/day after conversion from different time basis given by respondents).

The mean per capita consumption $\left(P_{i j}\right)$ of species $i$ for household $j$, with adjustment by age and gender class, was calculated as follows:

$$
P_{i j}=\frac{W_{i j}}{\sum_{k=1}^{m} \alpha_{k} A_{j k}}
$$

where $W_{i j}$ is as derived by the first equation, $A_{j k}$ is the number of persons for age-gender (age class for males, and for females) class $k$ in household $j, a_{k}$ is a correction factor for the age-gender class $k$, and $m$ is the number of age-gender classes. The factor $c_{i}$ was assumed to be 0.8 for all species and $a_{k}$ was based on the values in Kronen et al. (2006), but with a slight modification of the age and gender classes.

All statistical calculations, inferential hypothesis testing, and graphic presentations were performed on the IBM SPSS 19 and Microsoft Excel software. 


\section{Results}

\subsection{Demographics}

Subjects ranged in age from $<2$ years old ( $4 \%$ of sample) to over 60 years ( $1 \%$ of sample). Overall, $53 \%$ were male, $84 \%$ were Saudis (16\% were expatriates), and $41 \%$ were between 20 and 40 years (the primary reproductive age) (Total $\mathrm{N}=1000$ ). However, the 10 20 year olds are either in the reproductive phase, or soon will be. $62 \%$ were in the $10-40$ year old age group, of which $47 \%$ were female. Thus, 284 were women of child-bearing age. $4.3 \%$ of the females were pregnant at the time of the survey $(3.9 \%$ for Saudis; $6.4 \%$ for Expatriates). Of expatriates, about 79\% were from nearby countries (Middle East/North Africa), $13 \%$ from Asia, $6 \%$ from Africa, and 2\% from Europe/North America. While the median residency of Saudi Arabians was 21-25 years, for expatriates it was $<5$ years (which relates to total exposure time). The mean Saudi household had $5.4 \pm 2.7$ members, while the mean expatriate household had $5.2 \pm 2.5$ members, which as rather similar.

\subsection{Fishing and purchasing behavior}

For Saudi households, $3.7 \%$ of males and $4.3 \%$ of females do not eat fish: for expatriates, the percent not eating fish was $6.6 \%$ and $6.1 \%$ respectively. Most people eat fish at home (92\% Saudis, $97 \%$ expats), and many eat fish at restaurants (65\% and $48 \%$, respectively). The criteria people used in deciding which fish to purcahse were similar for Saudis and expats. Both mentioned that quality was the primary consideration when purchasing fish (about $70 \%$ of respondents), followed by freshness (40-45\% of respondents), and then price (20-22\%). Other reasons included source, taste, convenience, and fishing ground (local or not).

Most households obtained their fish from fish markets or supermarkets (Table 2). $23 \%$ of Saudi households, and $18 \%$ of expats had members that engaged in recreational fishing, and they all ate their fish. Most (over $80 \%$ ) fishing was by hook and line, although some people used spears, traps, or gill nets (about 18-25\%).

\subsection{Fish consumption}

Saudis included fish in their diets an average of $1.4 \pm 1.2 /$ week at home and $0.8 \pm 0.7$ meals/ week at restaurants, while expats ate $2.0 \pm 1.7 \mathrm{meals} /$ week at home and $1.1 \pm 1.1 \mathrm{meals} /$ week in restaurants. Thus, Saudis were eating 2.2 meals/week, while expats were eating 3.1 meals/ week. Meal frequency differed somewhat for Saudis and expatriates. However, in general there was remarkable concordance in the percent of people eating the seven most common species of fish for the two groups (Kendall tau correlation $=.90, \mathrm{p}=0.0014$, Table 3). For both groups "Hamour" or Grouper (including both Epinephelus and Cephalopholis) were preferred fish, eaten by $72 \%$ and $60 \%$ respectively. Plectropomus pessuliferus was the second favorite for both groups and Hipposcarus harid and Lethrinus lentjan were in $3^{\text {rd }}$ and $4^{\text {th }}$ place in terms of percentage of respondents saying they ate those species.

However, expatriates ate either larger portions and/or more frequent meals. The average of the mean meal sizes was $68 \mathrm{~g}$ for Saudis and $128 \mathrm{~g}$ for expatriates. Likewise the average meal size for the $90^{\text {th }}$ percentile $172 \mathrm{~g}$ vs $212 \mathrm{~g}$. Thus for Saudis the risk from the 
contaminants in fish is somewhat lower than for the expatriates because of average meal size. The most striking difference in fish consumption, however, was for two species that were unpopular with both groups. Plectropomus areolatus was eaten by $1 \%$ of Saudis and $2 \%$ of expatriates, but the meal size was $60 \mathrm{~g}$ for Saudis vs $329 \mathrm{~g}$ reported for expatriates. This is a very large quantity to be reported as a mean for any fish. Moreover, no Saudis reported eating Chanos chanos, which was eaten by $3 \%$ of expatriates with a $250 \mathrm{~g}$ average meal size.

Consumption rates (g/day) for the population overall are shown in Table 4. Since both frequency of meals and meal size varied between Saudis and expatriates, we examined them separately (Tables 5, 6). As is clear, there are not only ethnic differences, but differences in preferences for particular fish species.

\section{Discussion}

\subsection{Methodological issues}

Self-reported fish consumption is the usual method of determining exposure, and Jaarvinen et al. (1993) found that dietary recall data are reproducible and acceptable. Consumption histories have been validated by other methods, including biomarkers (levels of contaminants in tissues). Mercury concentration in hair reflect fish intake. A study of hair from 13 countries showed that mercury levels increased with increasing fish consumption (Airey, 1983). Both fish consumption by recall, and mercury intake, are positively associated with mercury levels in hair (Johnsson et al., 2004; Schoeman et al., 2010; Freire et al., 2010), including in pregnant women (Xue et al., 2007). There is also a significant correlation between mercury levels in blood and mercury intake by fish consumption (Knobeloch et al., 2003, 2006). Similarly, there is a significant correlation between fish consumption and biomarkers of inorganic mercury (Passos et al., 2007). There are far more studies on different tissue components for mercury than for other contaminants. Further, dioxins, PCBs and methylmercury in human tissues reflect fish consumption rates (Turunen et al., 2010). In general, increasing fish consumption (as determined by surveys and interviews) results in increasing biomarker values. Thus, fish consumption results in exposure to these contaminants.

On the contrary, there are some studies that suggest that the correlation (although significant) is not high. For example, Lucas et al., (2008) estimated that the overall correlation between EPA+DHA estimated from dietary recall of fish consumption by type and measured RBC EPA+DHA was only 0.37. Similarly, Mozzafarian et al. (2011) estimated that the correlation between toenail $\mathrm{Hg}$ and either fish consumption or selfreported fish intake was only 0.39 . In general, fish consumption studies (recall) provide approximate actual consumption as indicated by biomarkers of exposure, although determining intake from a small number of consumption days (e.g. $24 \mathrm{hr}$ recall, 2-3 day recall) over-estimates the upper percentiles of exposure (Jarvinen et al. 1993, Tran et al., 2004). It should also be noted, however, that under-reporting dietary intake seems to be more common in women than men, and in less well-educated populations (Klesges et al., 1995). Both of these factors might increase the risk to at-risk populations (e.g. women of child-bearing age). Since then, however, considerable attention devoted to the approaches 
and questions asked on consumption recall studies have no doubt contributed to more realistic reports (EPA, 1998, 2001, 2008), including the use of fish models to estimate size of fish meals (Burger et al., 1999).

There is considerable discussion about whether preparation or cooking practices affect the contaminants absorbed by the body. Since PCBs are stored in fat tissue, removing fat from fish (sometimes along the abdomen) reduces exposure to PCBs (ATSDR, 2000). Baking, frying, broiling, boiling, and microwaving fish all resulted in reducing the concentration of $\Sigma$ DDT and PCBs in fish tissue, but not mercury (Wilson et al., 1998). Accordingly, consumption information for different cooking methods was obtained in this study. For the top ten fish species consumed in the Jeddah study, $68.9 \%$ were fried, $28.1 \%$ were grilled, $7.4 \%$ were boiled, and $12 \%$ were baked in the oven.

\subsection{Preferences for different fish}

It is not surprising that people prefer some species of fish over others. However, most studies of fish consumption do not examine consumption patterns by fish species, or do so for only one or a very few species of fish. In this study, we examined preferences for 13 of the most commonly consumed fish from the Jeddah region. The groupers, however, contained many species because they are not generally distinguished by the local population. Overall consumption, however, varied greatly among these fish (and grouper group). Groupers were preferred, followed by trout, and emperor fish. Thereafter, preferences dropped markedly.

The clear preferences for a very few kinds (or types) of fish suggest that attention should be directed to both the advantages and disadvantages of consuming these fish in terms of contaminants, availability (e.g. are they being fished out), omega-3s, and other positive health benefits. Further, the use of these fish reflects mainly quality, freshness, and to a lesser degree, price, according to the respondents. Clearly, quality is a subjective effect of consumer belief (Olsen, 1999), but is one that managers must take into account. Presumably, freshness is linked to sensory cues about the degree of fish deterioration or spoilage. It should be noted, however, that consumer judgment of freshness may not be indicative of overall quality (Juhl and Poulsen, 2000).

\subsection{Ethnic differences}

Where consumption information or biomarkers of exposure are not available, risk assessors usually use default values derived from the US EPA (Strauss, 2004). While this is the best practice given the lack of exposure information, the resultant risk assessment are weakened by the great deal of variability in fish consumption (and thus exposure) patterns. We examined consumption patterns to have site-specific data on consumption rates for different species of fish, which allows for determinations of risk from specific fish species. In general, consumption varies from region to region of a country (Imm et al., 2007), and even within a given region or area. Fish consumption varies markedly as a function of ethnicity, age, income, and a range of other factors (Garcia-Closas et al., 1993; Connelly et al., 1996; Buck et al., 2000; Burger et al., 2001a,b; Burger and Gochfeld, 2011; Gochfeld and Burger, 2011; Nahab et al., 2011), especially in societies where cultural mores are changing (Burger et al., 
2003). Average consumption rates of specific ethnic groups may be many times higher than for the general population, particularly for tribal, low-income, or subsistence populations (Judd et al., 2004). Further, fish consumption patterns vary with perceptions about personal weight, health, and income (Trondsen et al., 2004). The present study provided site-specific data on fish consumption, which could be used for risk assessment studies.

Saudi Arabia is unusual in that there is a rather sedentary Saudi population along the coast that is consuming fish, and has done so for $20+$ years. There is also a population of expatriates that have come to work in the oil-related industries. This influx of labor creates a second group of fish consumers that have much lower residencies (less than 5 years), are likely to be larger bodied, and may have very different preferences for fish, and for particular fish species. Unfortunately, due to cultural sensitivities, we were unable to obtain information on income and education, but it is likely that the incomes (and educational level) of expatriates were higher than the overall coastal Saudi population sampled.

The Saudi traditional diet, rich in fiber and low in fat and cholesterol, has been increasingly westernized by the influx of expatriate labor as a result of the oil-based economic boom in the Kingdom (Kumosani et al., 2011). The shift was due to a change in eating habits and lack of knowledge, rather than a limitation to the traditional Saudi diet. A strategic plan for a consumption advisory program requires site-specific data on current diet, and we provide this information for fish consumption.

\subsection{Management implications}

The possible risk from contaminants in fish consumed by people is of great public health concern, as well as an environmental justice issue in some places (EPA, 1994, 2002, 2009a; Burger and Gochfeld, 2011). Governments can respond to the risk from contaminants in fish by source reduction, physical barriers to either the movement of pollutants or people wishing to fish, or by changing human behavior. In the latter case, responsibility for pollution is shifted from governmental agencies to individual people. In most cases, governmental agencies and organizations respond to contaminants in food by issuing guidelines or consumption advisories (FAO, 2003; EC, 2008; EPA, 2009b; USFDA, 2001, 2003). The objective of the present paper was to provide site-specific information on fish consumption that can be used by health professionals, governmental agencies, and public policy makers to examine potential risk from contaminants in the fish that they eat. While the government solicited this information through funding, it was less willing to issue consumption advisories. Partly, information on consumption (and on contaminants in fish) has not been available to the government, nor have these agencies considered issuing advisories. The information is under consideration by the government, which is well aware of its responsibility for the health of its citizens. This information can also be used by fisheries regulators to understand preferences for particular fish species, and by economists to consider in food economics.

\section{Acknowledgments}

This research was funded by the Saudi Arabian Ministry of Agriculture (MoA) to KAUST (KAUST/MoA 228211), with additional funds to JB and MG from EOHSI, NIEHS (P30ES005022), and Rutgers University. The support and assistance extended by the KAUST Administration and CMOR staff are deeply appreciated. We thank also the 
many people who have discussed these topics with us, or who have helped in the research, including R. Schoeny, A. Stern, D. Carpenter, N. Ralston, M. Lemiré, D. Mergler, S. Silbernagel, E. Silbergeld, E. Groth, C. Chess, C. Jeitner, T. Pittfield, and M. Donio. We also gratefully acknowledge the logistical help provided by C. Jeitner. The views and opinions expressed in this paper are those of the authors, and do not represent the funding agencies.

\section{References}

Airey D. Total mercury concentrations in human hair from 13 countries in relation to fish consumption and location. Science of the Total Environ. 1983; 31:157-180.

Anderson, PD.; Wiener, JB. Eating fish. In: Graham, JD.; Wiener, JB., editors. Risk versus risk: tradeoffs in protecting health and the environment. Cambridge, Mass: Harvard Univ Press; 1995. 1995.

Agency for Toxic Substances and Disease Registry (ATSDR). Atlanta GA: Agency for Toxic Substances and Disease Registry; 2000. Toxicological Profile for Polychlorinated biphenyls (PCBs. http://www.atsdr.cdc.gov/toxprofiles/tp17.pdf [Accessed Sept 18 2009]

Bienenfeld LS, Golden AL, Garland EJ. Consumption of fish from polluted waters by WIC participants in East Harlem. Journal of Urban Health. 2003; 80:349-358. [PubMed: 12791809]

Buck GM, Vena JE, Schisterman EF, Dmochowski J, Mendola P, Sever LE, et al. Parental consumption of contaminated sport fish from Lake Ontario and predicted fecundability. Epidemiology. 2000; 11:388-383. [PubMed: 10874544]

Burger J, Gochfeld M. A framework and information needs for the management of the risks from consumption of self-caught fish. Environmental Research. 2006; 101:275-285. [PubMed: 16386241]

Burger J, Gochfeld M. Conceptual environmental justice model for evaluating chemical pathways of exposure in low-income, minority, Native American, and other unique exposure populations. American Journal of Public Health. 2001; 101:S64-S80. [PubMed: 21551379]

Burger J, Cooper K, Gochfeld M. Exposure assessment for heavy metal ingestion from a sport fish in Puerto Rico: estimating risk for local fishermen. Journal of Toxicology and Environmental Health. 1992; 36:355-365. [PubMed: 1507267]

Burger JW, Stephens CS, Boring CS, Kuklinski M, Gibbons JW, Gochfeld M. Factors in exposure assessment: Ethnic and socioeconomic differences in Fishing and Consumption of fish caught along the Savannah River. Risk Analysis. 1999; 19:427-438. [PubMed: 10765415]

Burger J, Gaines KF, Gochfeld M. Ethnic differences in risk from mercury among Savannah River fishermen. Risk Analysis. 2001a; 21:533-544. [PubMed: 11572431]

Burger J, Gaines KF, Boring CS, Stephens WL Jr, Snodgrass J, Gochfeld M. Mercury and selenium in fish from the Savannah River: species, trophic level, and locational differences. Environmental Research. 2001b; 87:108-118. [PubMed: 11683594]

Burger J, Fleischer J, Gochfeld M. Fish, shellfish, and meat meals of the public in Singapore. Environmental Research. 2003; 92:254-261. [PubMed: 12804522]

Chew, CM. Toxicity and Exposure Concerns Related to Arsenic in Seafood: An Arsenic Literature Review for Risk Assessments. Vol. 10. Region: U.S. Environmental Protection Agency; 1996. p. 51

Connelly NA, Knuth BA, Brown TL. Sportfish consumption patterns of Lake Ontario anglers and the relationship to health advisories. North American Journal of Fisheries Management. 1996; 16:90101.

Daviglus M, Sheeshka J, Murkin E. Health benefits from eating fish. Comments in Toxicology. 2002; 8:345-374.

Downs SG, Macleod CL, Lester JN. Mercury precipitation and its relation to bioaccumulation in fish: a literature review. Water Air Soil and Pollution. 1998; 108:149-187.

European Commission. Commission Regulations (EC) No. 629-2008 of 2 July 2008 amending Regulation (EC) No 188/2006 setting maximum levels for certain contaminants in foodstuffs. Off J EU. 2008; 51:4-10.

Food and Agricultural Organization (FAO). Geneva: Food and Agriculture Organization (FAO), World Health Organization (WHO); 2003. Joint FAO/WHO expert Committee on food additives. 
Feidi, IH. Fisheries development in the Arab world. Section IV: Marine Environments. In: Coppock, J.; Miller, JA., editors. Transformation of Middle Eastern Natural Environments: Legacies and Lessons. New Haven, Connecticut: Yale School of Forestry and Environmental Studies, Yale University; 1998. p. 388-406.Bulletin No. 103

Freire C, Ramos R, Lopez-Espinosa MJ, Diez S, Vioque J, Ballester F, et al. Hair mercury levels, fish consumption, and cognitive development in preschool children from Granada, Spain. Environmental Research. 2010; 110:96-104. [PubMed: 19909946]

Garcia-Closas R, Serr-Majem L, Segura R. Fish consumption, 4-3 fatty acids and the Mediterranean diet. European Journal of Clinical Nutrition. 1993; 47:85-93.

Gochfeld M, Burger J. Disproportionate exposures in environmental justice and other populations. American Journal of Public Health. 2011; 101:S37-S63. [PubMed: 22028451]

Hsiao H, Ullrich SM, Tanton TW. Burdens of mercury in residents of Temirtau, Kazakhstan. 1: hair mercury concentrations and factors of elevated hair mercury levels. Science of the Total Environment. 2011; 409:2272-2280. [PubMed: 20092877]

Imm P, Knobeloch L, Anderson HA. Maternal recall of children's consumption of commercial and sport-caught fish: findings from a multi-state study. Environmental Research. 2007; 103:198-204. [PubMed: 16828736]

Institute of Medicine (IOM). Seafood Choices: Balancing benefits and risks. Washington, DC: National Academy Press; 2006.

Jarvinen R, Seppanen R, Knekt P. Short-term and long-term reproducibility of dietary history interview data. Internstional Journal of Epidemiology. 1993; 22:520-527.

Jewett SC, Zhang X, Naidu AS, Kelley JJ, Dasher D, Duffy LK. Comparison of mercury and methylmercury in northern pike and Arctic grayling from western Alaskan rivers. Chemosphere. 2003; 50:386-392.

Johnsson C, Sallsten G, Schutz A, Sjors A, Barregard I. Hair mercury levels versus freshwater consumption in household members of Swedish angling societies. Environmental Research. 2004; 96:257-263. [PubMed: 15364592]

Judd N, Griffih WC, Faustman EM. Contribution of PCB exposure from fish consumption to total dioxin-like dietary exposure. Regulatory Toxicology and Pharmacology. 2004; 40:125-135. [PubMed: 15450716]

Juhl HJ, Poulsen CS. Antecedents and effects of consumer involvement in fish as a product group. Appetite. 2000; 34:261-267. [PubMed: 10888289]

Klesges RC, Eck LH, Ray JW. Who underreports dietary intake in a dietary recall? Evidence from the Second National Health and Nutrition Examination Survey. Journal of Consulting and Clinical Psychology. 1995; 63:438-444. [PubMed: 7608356]

Knobeloch L, Anderson HA, Imm P, Peters D, Smith A. Fish consumption, advisory awareness, and hair mercury levels among women of childbearing age. Environ Res. 2003; 97:220-227. [PubMed: 15533338]

Knobeloch L, Steenport D, Schrank C, Anderson H. Methylmercury exposure in Wisconsin: a case study series. Environmental Research. 2006; 101:113-122. [PubMed: 16198333]

Kris-Etherton PM, Harris WS, Appel LJ. Fish consumption, fish oil, omega-3 fatty acides, and cardiovascular disease. Circulation. 2002; 106:2747-2757. [PubMed: 12438303]

Kumosani TA, Alama MN, Iyer A. Cardiovascular diseases in Saudi Arabia. Prime Research on Medicine. 2011; 1:1-6.

Lansens P, Leermakers M, Vaeyens W. Determination of methylmercury in fish by headspace-gas chromatography with microwave-induced-plasma detections. Water, Air, and Soil Pollution. 1991; 56:103-115.

Lu YZ, Yan BX, Wang MJ, Guo LY. The evolution rule and ecology risk assessment of mercury in fish of Gonghua River. Journal of Agro-Environmental Science. 2008; 27:2430-2433.

Mozaffarian D. Fish, mercury, selenium and cardiovascular risk: current evidence and unanswered questions. International Journal of Environmental Research and Public Health. 2009; 6:18941916. [PubMed: 19578467]

Mozaffarian D, Rimm EB. Fish intake, contaminants, and human health: evaluating the risks and the benefits. Journal of American Medicine Association. 2006; 296:1885-1899. 
Nahab F, Le A, Judd S, Frankel MR, Ard J, Newby PK, Howard VJ. Racial and geographical differences in fish consumption. Neurology. 2011; 76:154-158. [PubMed: 21178096]

National Ocean and Atmospheric Association (NOAA). NOAA Magazine, U.S. Commerce Dept., National Oceanographic and Atmospheric Administration; 2004. Seafood consumption rose again in 2003. hhtp://www.noaanews.noaa.gov/stories2004/s2322.htm 2004. [accessed 10 March 2005]

Oken E, Radesky JS, Wright RO, Bellinger DC, Amarasiriwardena CJ, Kleinman KP, et al. Maternal fish intake during pregnancy, blood mercury levels, and child cognition at age 3 years in a US cohort. American of Journal of Epidemiology. 2008; 167:1171-1181.

Olsen SO. Strength and conflicting valence in the measurement of food attitudes and preferences. Food Quality Preference. 1999; 10:483-494.

Olsen SF, Secher NJ. Low consumption of seafood in early pregnancy as a risk factor for preterm delivery: prospective cohort study. British Medical Journal. 2002; 324(7335):447. [PubMed: 11859044]

Olsen SF, Østerdal ML, Salvig JD, Kesmodel U, Henriksen TB, Hedegaard M, et al. Duration of pregnancy in relation to seafood intake during early and mid pregnancy: prospective cohort. European Journal of Epidemiology. 2006; 21:749-758. [PubMed: 17111251]

Passos CJS, Mergler D, Lemire M, Fillion M, Guimaraes JRD. Fish consumptions and bioindicators of inorganic mercury exposure. Science of the Total Environment. 2007; 373:68-76. [PubMed: 17198723]

Patterson J. I ntroduction---comparative dietary risk: balance the risks and benefits of fish consumption. Comments in Toxicology. 2002; 8:337-344.

Ramel A, Martinez JA, Kiely M, Bandarra NM. Moderate consumption of fatty fish reduces diastolic blood pressure in overweight and obese European young adults during energy restriction. Nutrition. 2010; 26:168-174. [PubMed: 19487105]

Rice G, Swartout J, Mahaffey K, Schoeny R. Derivation of U.S. EPA's oral Reference Dose (RfD) for methylmercury. Drug and Chemical Toxicology. 2000; 23:41-54. [PubMed: 10711388]

Sidhu KS. Health benefits and potential risks related to consumption of fish or fish oil. Regulatory Toxicology and Pharmacology. 2003; 38:336-344. [PubMed: 14623484]

Sioen I, Camp JV, Verdonck F, Verbeke W, Vanhonacker F, Willems J, et al. Probabilistic intake assessment of multiple compounds as a tool to quantify the nutritional-toxicological conflict related to seafood consumption. Chemosphere. 2008; 71:1056-1066. [PubMed: 18155748]

Stern AH, Jacobson JL, Ryan L, Burke TA. Do recent data from the Seychelles Islands alter the conclusions of the NRC Report on the toxicological effects of methylmercury? Environmental Health. 2004; 3:2. [PubMed: 14754462]

Strauss H. Sportsfish consumption surveys: a risk assessment practitioner's wish list. Human Ecology and Risk Assessment. 2004; 10:1213-1225.

Sun YHC. Health concern, food choice motives, and attitudes toward healthy eating: The mediating role of food choice motives. Appetite. 2008; 51:42-49. [PubMed: 18187232]

Toth JF Jr, Brown RB. Racial and gender meanings of why people participate in recreational fishing. Leisure Science. 1997; 19:129-146.

Tran NL, Barraj L, Smith K, Javier A, Burke TA. Combining food frequency and survey data to quantify long-term dietary exposure: a methylmercury case study. Risk Analysis. 2004; 24:19-30. [PubMed: 15027997]

Trondsen T, Braaten T, Lund E, Eggen AE. Consumption of seafood - the influence of overweight and health beliefs. Food Quality Preference. 2004; 15:361-374.

Turunen AW, Mannisto S, Kiviranta H, Marniemi J, Jula A, Tittanen P, et al. Dioxins, polychlorinated biphenyls, methylmercury and omega-3 polyunsaturated fatty acids as biomarkers of fish consumption. European Journal of Clinical Nutrition. 2010; 1:1-11.

United States Environmental Protection Agency (USEPA). Washington, DC: United States Environmental Protection Agency (USEPA); 1994. Environmental justice initiatives 1993. (EPA 2000-R-93-001).

United States Environmental Protection Agency (USEPA). Washington, DC: United States Environmental Protection Agency (USEPA); 1998. Guidance for conducting fish and wildlife consumption surveys. EPA-823-B-98-007 
United States Environmental Protection Agency (USEPA). Washington DC: United States Environmental Protection Agency (USEPA); 2001. General principles for performing aggregate exposure and risk assessments.

United States Environmental Protection Agency (USEPA). Washington DC: United States Environmental Protection Agency (USEPA); 2002. National Environmental Justice Advisory Council: fish consumption and environmental justice, 2002. http://www.epa.gov/compliance/ resources/publications/ej/fish_consump_report_1102.pdf [Accessed April 5, 2009]

United States Environmental Protection Agency (USEPA). Washington, DC: United States Environmental Protection Agency (USEPA); 2008. Concepts, methods, and data sources for cumulative health risk assessment of multiple chemicals, exposures and effects: a resource document. http://cfpub.epa.gov/ncea/cfm/recordisplay.cfm?deid=190187 [Accessed May 2008]

United States Environmental Protection Agency (USEPA). Washington, DC: United States Environmental Protection Agency (USEPA); 2009a. Environmental justice: compliance and enforcement. http://www.epa.gov/environmentaljustice [Accessed February12, 2009]

United States Environmental Protection Agency (USEPA). Washington, DC: United States Environmental Protection Agency (USEPA); 2009b. National listing of fish advisories: technical fact sheet: 2008 biennial national listing. http://www.epa.gov/fishadvisories/tech2008.htm [Accessed February 12, 2009]

United States Food and Drug Administration (USFDA). Washington, DC: US Food and Drug Administration (USFDA); 2001. FDA consumer advisory. U.S. http//www.fda.gov/bbs/topics/ ANSWERS/2000/advisory.html [Accessed December 2001]

United States Food and Drug Administration (USFDA). Washington, DC: Food and Drug Administration; 2003. FDA consumer advisory. Available: http//www.fda.gov/bbs/topics/ ANSWERS/2000/advisory.html. U.S. 2003 [Accessed January 1, 2004]

Virtanen JK, Mozaffarian D, Chiuve SE, Rimm EB. Fish consumption and risk of major chronic disease in men. American Journal of Clinical Nutrition. 2008; 88:1618-1625. [PubMed: 19064523]

Verbeke M, Vackier I. Individual determinants of fish consumption: application of the theory of planned behavior. Appetite. 2005; 44:67-82. [PubMed: 15604034]

Wilson ND, Shear NM, Faustenbach DJ, Price PS. The effect of cooking practices on the concentration of DDT and PCB compounds in the edible tissue of fish. Journal of Exposure of Environmental Epidemiology. 1998; 8:423-440.

York R, Gossard MH. Cross-national meat and fish consumption: exploring the effects of modernization and ecological context. Ecological Economics. 2004; 48:293-302.

Xue F, Holzman C, Rahbar MH, Trosko K, Fischer L. Maternal fish consumption, mercury levels, and risk of preterm delivery. Environmental Health Perspectives. 2007; 115:42-54. [PubMed: 17366817] 


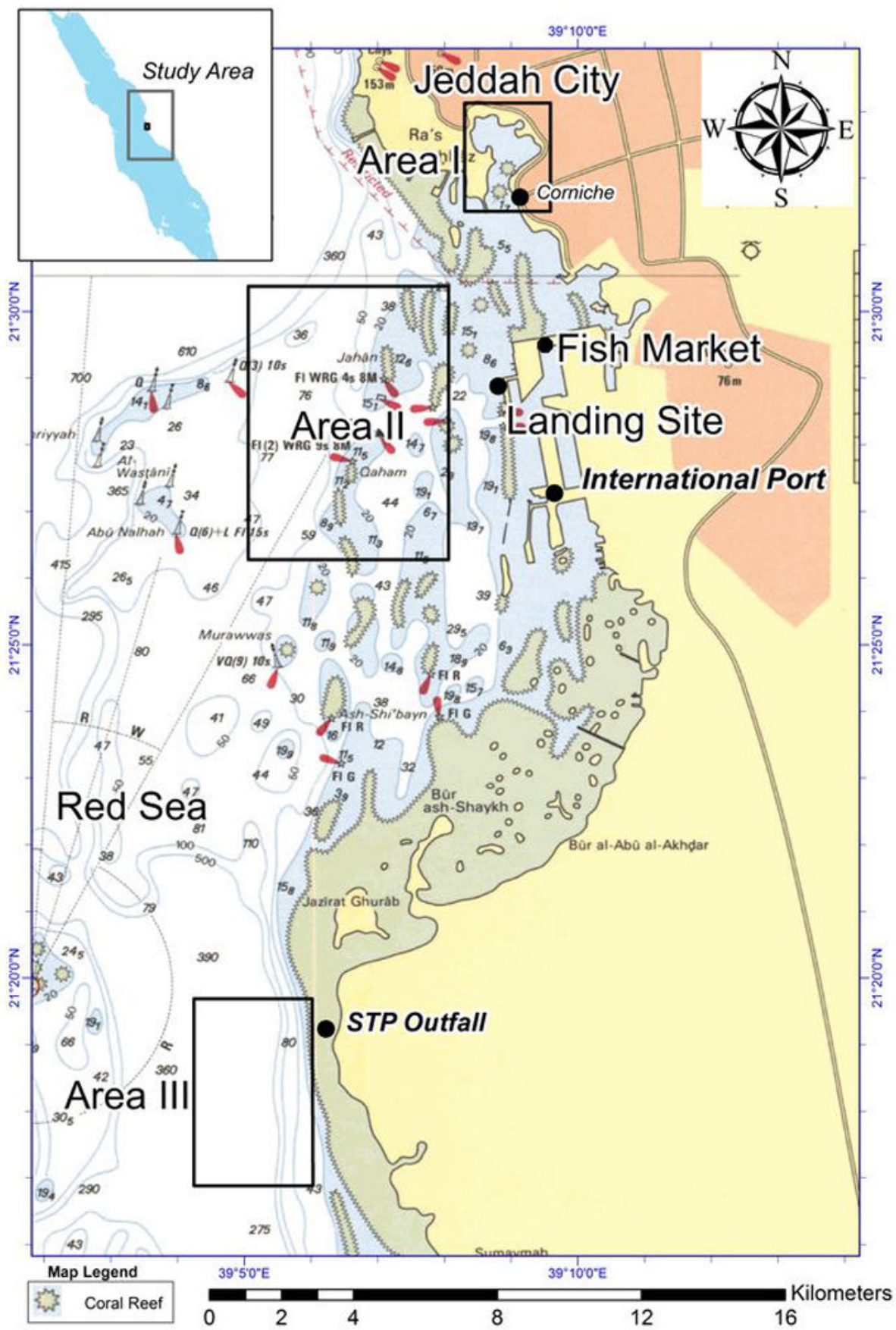

Figure 1.

Map of the Jeddah region where fish consumption was examined. 


\section{Table 1}

List of examined fish species for metal and organic contaminants in edible tissues.

\begin{tabular}{lll}
\hline Scientific Name & Common English & Local Name \\
\hline Apharius rutilans & Sole & Mosa, Faris \\
Cephalopholis argus & Grouper & Hamour \\
Carangoides bajad & Orange-spotted trevally & Bayad \\
Chanos chanos & Milkfish & Salmani \\
Ephinephelus tauvina & Grouper & Hamour \\
Hipposcarus harid & Parrotfish & Harid \\
Lutjanus bohar & Red snapper & Bohar \\
Lethrinus lentjan & Emperor & Shaoor, Krseit, Sheiry \\
Mugil cephalus & Mullet & Arabi, Bori \\
Plectropomus areolatus & Squaretail grouper & Tarathi \\
Plectropomus pessuliferus & Coral trout (grouper) & Najil \\
Siganus rivulatus & Rivulated rabbitfish & Sijan, Safi \\
Variola louti & Moontail seabass (grouper) & Louit, Shareef, Shrefi \\
\hline
\end{tabular}




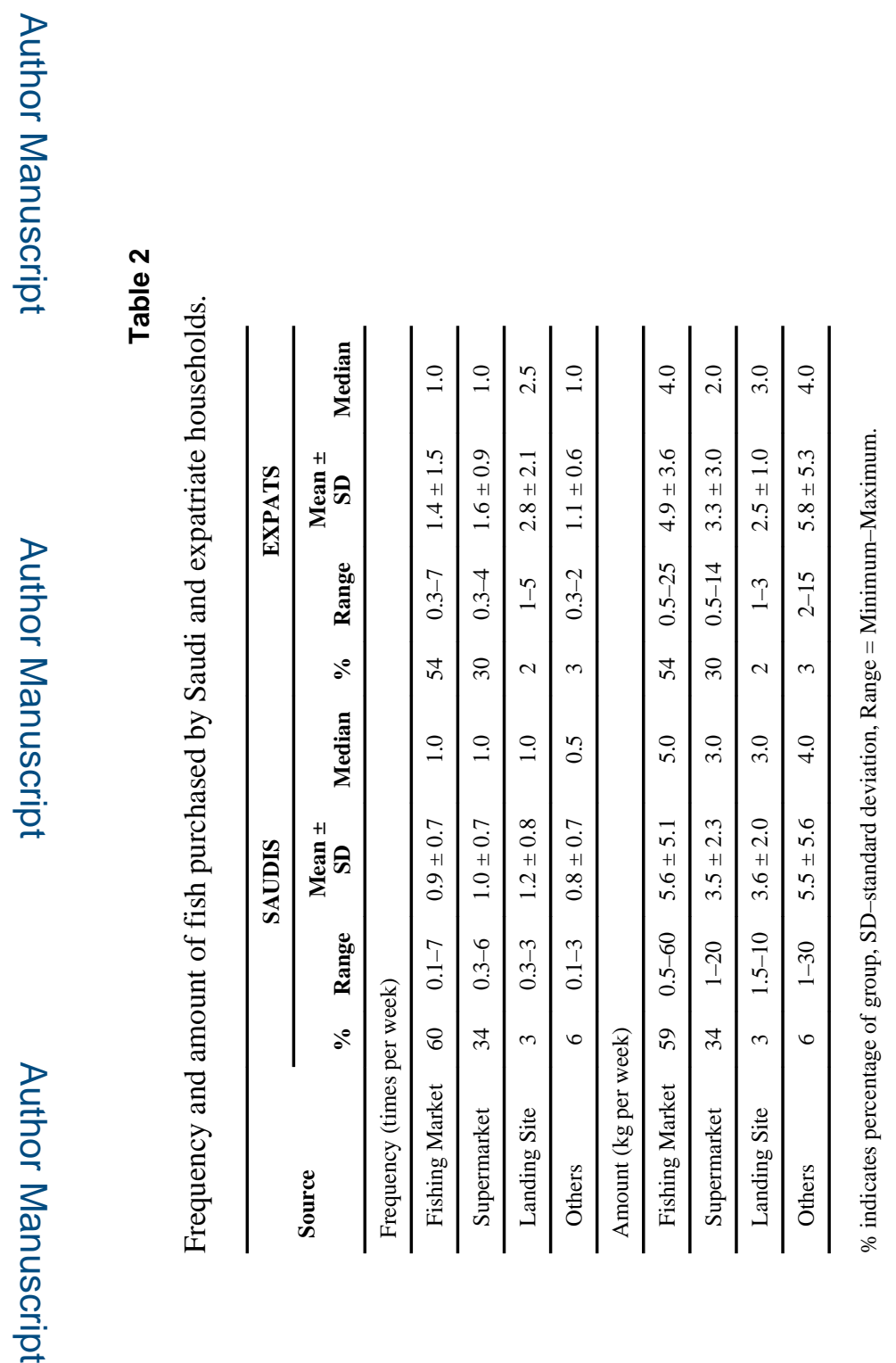




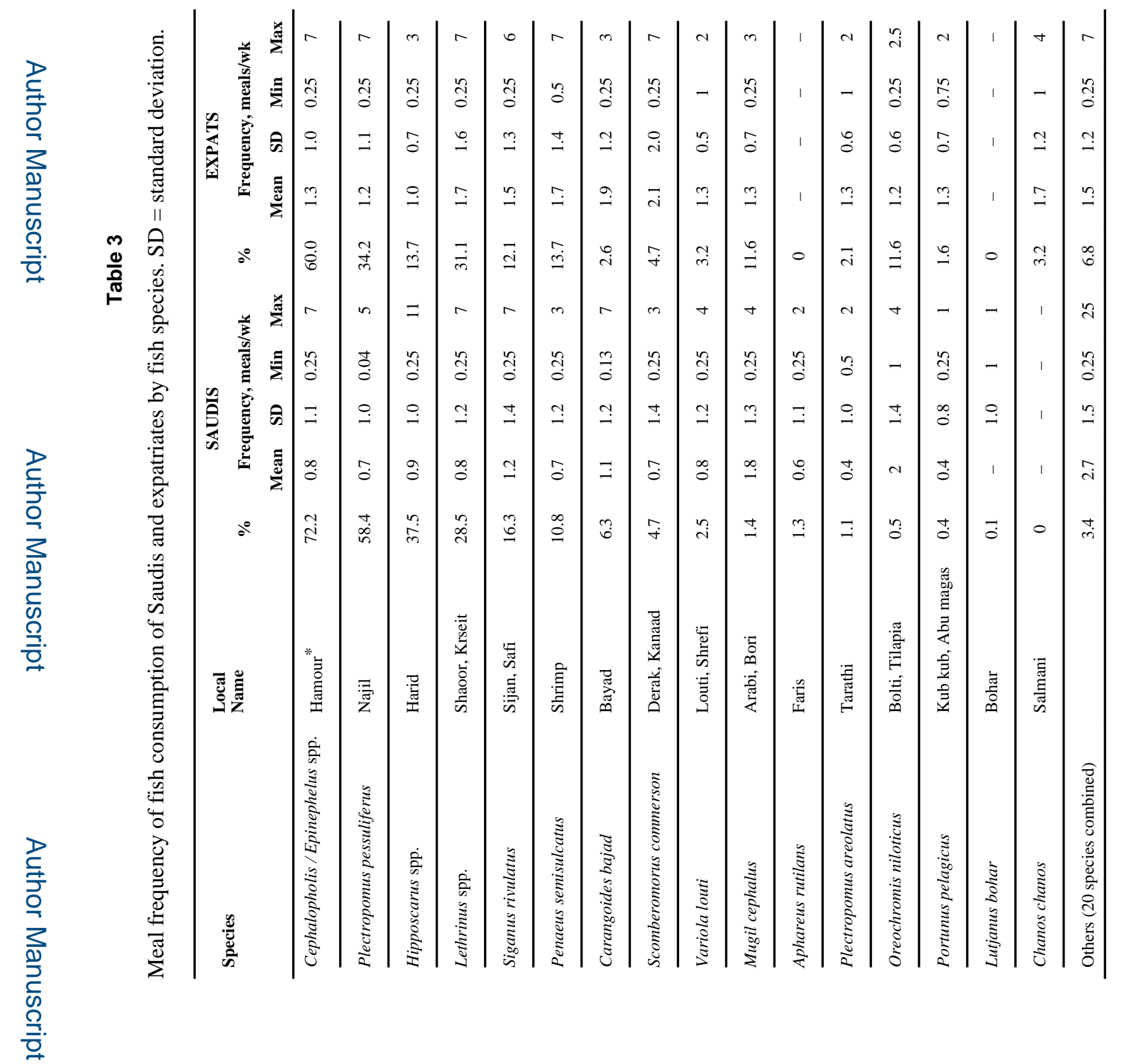

Environ Res. Author manuscript; available in PMC 2015 June 15. 


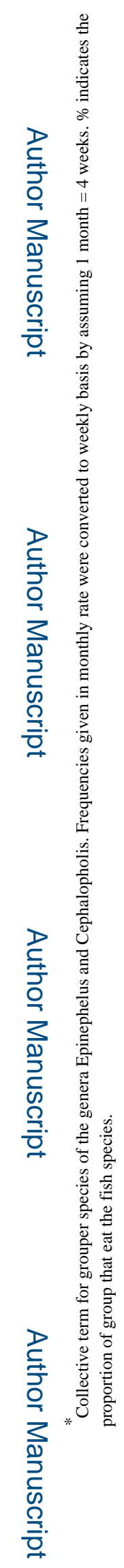

Environ Res. Author manuscript; available in PMC 2015 June 15. 


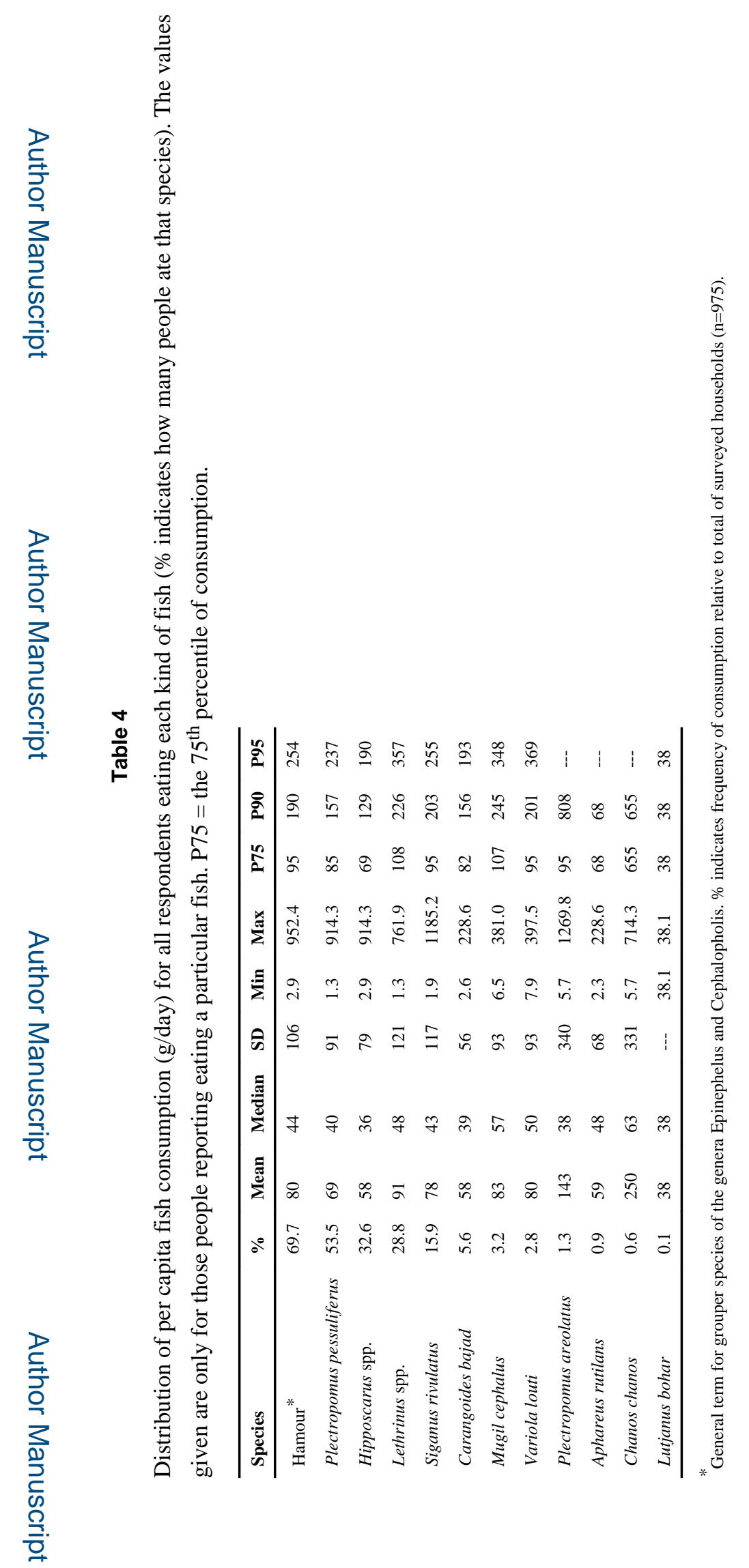

Environ Res. Author manuscript; available in PMC 2015 June 15. 


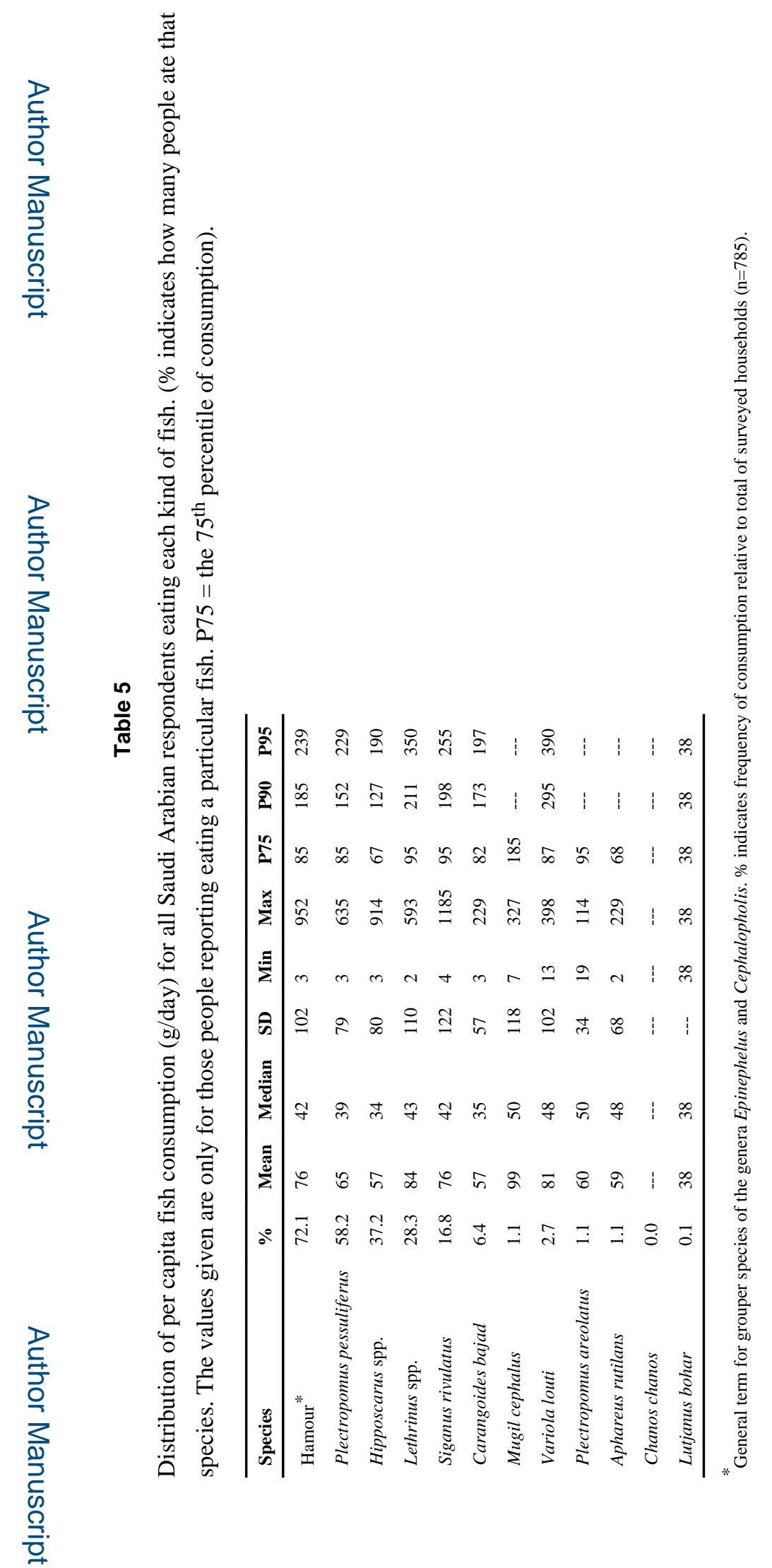

Environ Res. Author manuscript; available in PMC 2015 June 15. 


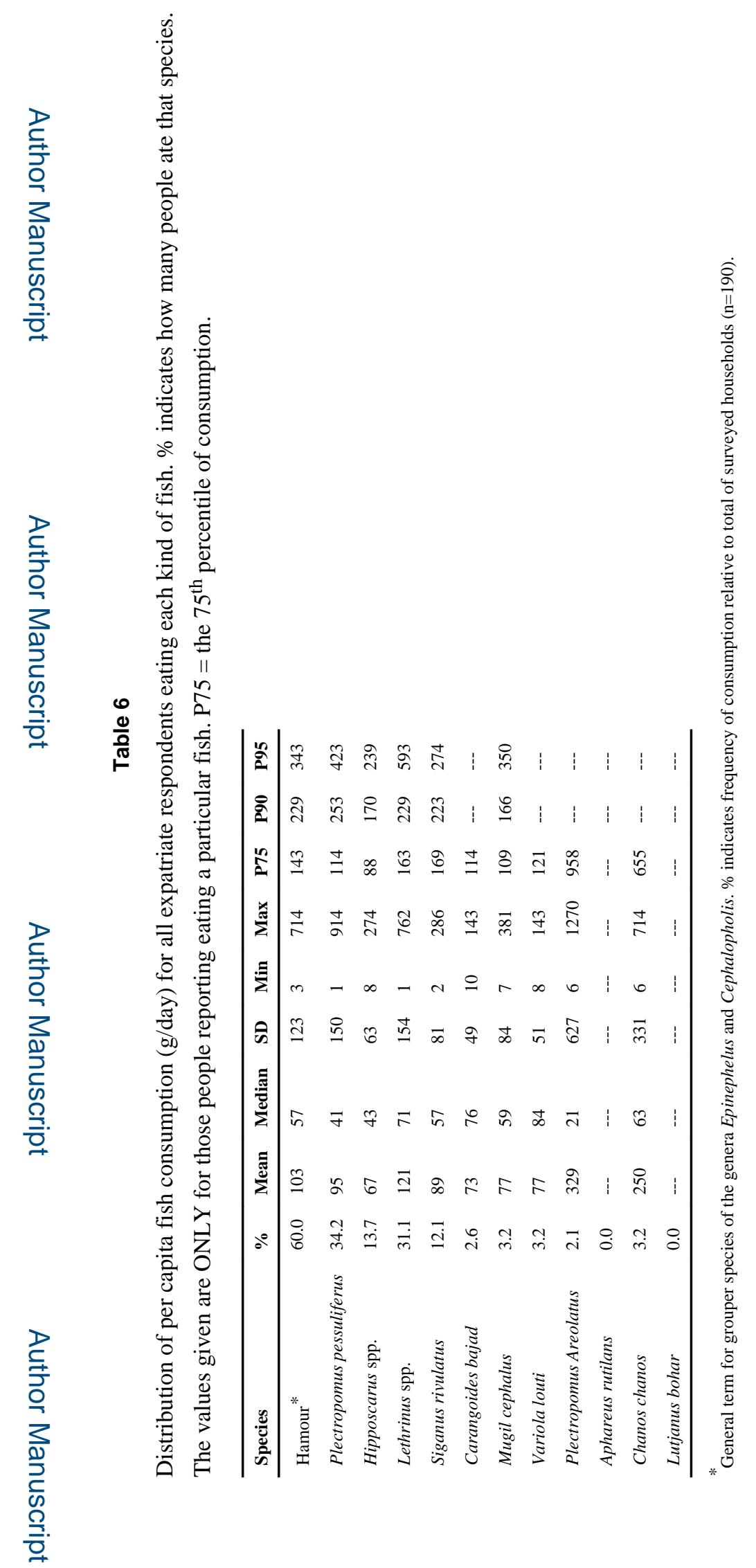

Environ Res. Author manuscript; available in PMC 2015 June 15. 